\title{
Kuraklık Stresi ve Bitki Proteomiği
}

\author{
Drought Stress and Plant Proteomics
}

\author{
Mustafa YILDIZ*a ${ }^{\text {, Fadimana KAYA }}{ }^{\mathrm{b}}$, Hakan TERZI ${ }^{\mathrm{c}}$ \\ Afyon Kocatepe Üniversitesi, Fen Edebiyat Fakültesi, Moleküler Biyoloji ve Genetik Bölümü, 03100, Afyonkarahisar
}

• Geliş tarihi / Received: 21.05.2019 • Düzeltilerek geliş tarihi / Received in revised form: 11.10.2019 • Kabul tarihi / Accepted: 22.10 .2019

\begin{abstract}
$\ddot{O} z$
Hayatta kalabilmek için bitkilerin stresle sürekli başa çıkmaları gerekir. Kuraklık bitki büyümesini, gelişimini ve ürün verimliliğini etkileyen ana abiyotik streslerden biridir. Bitki sslahı çalışmaları kapsamında, kuraklık stresine karşı dayanıklı ve yüksek besin değerine sahip tarımsal bitki türlerinin geliştirilmesi genomik, transkriptomik, proteomik ve metabolomik gibi "omik" teknolojileri ile sağlanabilecektir. Proteomik, kuraklık stresi koşullarında bir hücredeki proteinlerin tanımlanması, ifade seviyelerinin belirlenmesi, translasyon sonrası modifikasyonların ortaya konulması ve protein-protein etkileşimlerinin anlaşılması için güçlü bir yöntemdir. Farklı streslere maruz kalan bitkilerde protein ifade seviyesinde önemli değişiklikler meydana geldiğinden, proteomik yaklaşım stres koşulları altında proteinlerin stres toleransı ile ilişkisini aydınlatmak için oldukça önemlidir. Kuraklık stresi genellikle fotosentez, enerji metabolizması, stres savunma, protein metabolizması ve sinyal iletimi gibi yolaklarda fonksiyon gören proteinlerin ifade seviyelerinde değişime neden olmaktadır. Bitkilerde proteomik çalışmalarda fizyolojik ve moleküler sonuçların beraber değerlendirilmesi kuraklık toleransı için bazı potansiyel proteinler ya da metabolik yolakların keşfedilmesine olanak tanımaktadır. Bu derlemede, bitkilerin kuraklık stresine vermiş oldukları protein seviyesindeki tepkiler hakkındaki son bilgiler tartışılmıştır.
\end{abstract}

Anahtar kelimeler: Kuraklık Stresi, Kuraklık Toleransı, Proteomik, Savunma Mekanizmaları

\begin{abstract}
Plant need to overcome with stress to survive permanently. Drought is one of the major abiotic stresses that affect growing and developing of plants and productivity of crops. Within the scope of plant breeding studies, development of agricultural plant species which are resistant to drought stress and have high nutritional value will be provided by omics technologies such as genomics, transcriptomics, proteomics and metabolomics. Proteomics is a strong method for identification of proteins in a cell under drought stress conditions, determination of expression levels, introducing post-translational modifications, and understanding protein-protein interactions. Since there is a significant change in protein expression level in plants exposed to different stresses, the proteomics approach is quite important to elucidate the relationship of proteins to stress tolerance. Drought stress usually causes changes in expression levels of proteins that function in pathways such as photosynthesis, energy metabolism, stress defense, protein metabolism and signal transduction. Combination of physiological and molecular results in proteomic studies in plants allows the discovery of some potential proteins or metabolic pathways for drought tolerance. In this review, we discussed recent information on plant responses to drought stress at protein level.
\end{abstract}

Keywords: Drought Stress, Drought Tolerance, Proteomics, Defense Mechanisms

\footnotetext{
$*^{\mathrm{a}}$ Mustafa YILDIZ; mustafa_yildizus@yahoo.com, Tel: (0272) 22818 02, orcid.org/0000-0002-6819-9891

${ }^{\mathrm{b}}$ orcid.org/0000-0003-3173-1706 $\quad{ }^{\mathrm{c}}$ orcid.org/0000-0003-4817-1100
} 


\section{Giriş}

Fonksiyonel genomik ve transkriptomik analizler, bitkilerde kuraklığa duyarlı mekanizmaların moleküler temelini anlamak için yaygın olarak kullanılmaktadır (Rasheed vd., 2016; Moschen vd., 2017). Kuraklık stresi ile ilişkili genler ozmotik basınç düzenleyici enzimleri, akuaporinleri, detoksifiye edici enzimleri, LEA (late embryogenesis abundant) proteinlerini, reaktif oksijen türlerini temizleyen enzimleri ve hücre zarlarının bütünlügünü koruyan ve iyon taşınımı/dengesini sağlayan şaperonları kodlayan genlerdir. Ayrıca, gen ifadesi ve sinyal iletimini düzenleyen çeşitli transkripsiyon faktörleri ve protein kinazlar da kuraklık stresine yanitta önemlidir (Wei vd., 2009; Rasheed vd., 2016). Kuraklık stresi, bitkilerin canlıliklarının sürdürebilmesinde rol oynayan genlerin ifadesindeki değişimler, bitkilere zarar verebilen veya strese karşı tolerans sağlayacak bir mekanizmanın parçası olan proteinlerin üretimi ve degradasyonundaki değişimler ve kuraklık stresine tolerans sağlayabilen yeni metabolitlerin sentezi için metabolizmanın değiştirilmesi gibi etkileşimli modifikasyonlara neden olabilmektedir (Babita vd., 2010; Mohammadi vd., 2012; Batlang vd., 2013; Kumari vd., 2013). Kuraklık stresine adaptasyonda, stoma hareketlerinin düzenlenmesi, süberin sentezinin teşviki ve çiçek gelişiminde önemli rol oynayan MYB transkripsiyon faktörlerinin (Gao vd., 2014; Baldoni vd., 2015), primer ve sekonder metabolizma, gelişim ve farklı biyotik ve abiyotik streslere cevaptaki rolleri bilinmektedir (Gao vd., 2014; Kosma vd., 2014; Baldoni vd., 2015).

Bitki proteomiği, strese maruz kalan bitkilerde de bitki proteomunun ve proteinlerin biyolojik fonksiyonlarının araştırılmasına yönelik dinamik bir disiplindir. Son yıllarda, stres altındaki bitkilerin proteomundaki değişimleri konu alan çalışmaların sayısı giderek artmaktadır (Kosová vd., 2018). Strese maruz kalan bitkilerden elde edilen moleküler bilgiler, strese toleranslı bitkilerin genetik olarak geliştirilmesi için olas1 aday genlerin belirlenmesine olanak sağlamaktadır (Barkla vd., 2016). Farklı bitki türlerinde yapılan proteomik çalışmalar kuraklık stresine olan cevapların moleküler temellerinin anlaşılmasında önemli bilgiler sağlamıştır (Şekil 1) (Wang vd., 2016; Wang vd., 2017; Michaletti vd., 2018; Xin vd., 2018). Kuraklık stresinin proteom değişimleri üzerine etkisi bitki türlerine, genotiplere veya stresin şiddetine bağlı olarak farkl111k göstermesine karşın, proteomik analizler karbohidrat ve enerji metabolizmasının yanı sıra sinyal iletimi, reaktif oksijen türlerinin temizlenmesi, ozmotik düzenleme, protein sentezi ve işlenmesi, hücre yapısının düzenlenmesi ile ilişkili proteinlerin seviyelerinde önemli değişimler olduğunu göstermektedir. $\mathrm{Bu}$ derlemede, son yıllarda yapılan çalışmalar dikkate alınarak kuraklık stresinin bitki proteomunda neden olduğu değişimler tartışılmıştır.

\section{Kuraklık Stresi ve Proteomik}

Kuraklık stresi sırasında, çeşitli savunma mekanizmaları fizyolojik, biyokimyasal ve moleküler seviyelerde düzenlenmektedir (Şekil 2). Kuraklık stresi fotosentez, solunum, translokasyon, iyon alımı, su potansiyeli, stoma kapanmas1, şeker ve besin metabolizmas1, antioksidan sistem ve ayrica fitohormonlar gibi çeşitli fizyolojik ve biyokimyasal süreçleri etkileyerek bitki büyümesini etkilemektedir (Prasad vd., 2011). Kuraklığa cevap veren genlerin ekspresyon ürünleri esas olarak sinyal iletim yolaklarına ve transkripsiyonel regülasyona katılan proteinleri, hücresel membranları koruyan fonksiyonel proteinleri, absisik asit (ABA) biyosentezi ilişkili proteinleri ve LEA gibi diğer proteinleri içermektedir (Nakashima vd., 2014). Birçok proteomik çalışmada, bazı protein sınıflarının kuraklık stresine cevap olarak teşvik edildiği ve bu proteinlerin savunma ve uyum süreçlerinde önemli rol oynayabileceği gösterilmiştir (Khodadadi vd., 2017; Michaletti vd., 2018; Nemati vd., 2019).

\subsection{Fotosentez ile İlişkili Proteinler}

Fotosentez doğrudan bitki verimliliği ve enerji kullanımı ile ilişkilidir ve kuraklık stresi gibi birçok abiyotik stres faktörü fotosentezi etkilemektedir (Kosova vd., 2011). Kuraklık stresi sırasında büyüme ve gelişimin sürdürülmesinin yollarından biri, fotosentez etkinliğini mümkün olduğu kadar yüksek tutmak ancak stresten kaynaklanan enerji ve iyon dengesizliklerini önlemektir. $\mathrm{Bu}$ dengesizlikler fotosentetik aygıtların aşırı uyarılmasına ve sonuç olarak fotooksidatif hasara yol açabilir (Chaves vd., 2009). Bitkilerin olumsuz çevre koşullarına adaptasyonu, diğer süreçlerle birlikte bitki büyümesi ve gelişimini belirleyen fotosentezin plastisitesi ve esnekliği ile ilgilidir (Abreu vd., 2013). Fotosentetik bileşenlerin fonksiyonel olarak birbirleriyle ilişkili olduğu göz önüne alındığında, herhangi bir fotosentetik bileşenin zarar görmesi fotosentetik aktivitede genel bir azalmaya yol açabilmektedir (Chen vd., 2011). Elektron taşıma zinciri ve RuBisCO gibi karbon indirgenme 
döngüsünün önemli enzimlerinin kuraklık stresine bağlı olarak ifade seviyelerinin azaldığ 1 ve bu azalmanın fotosentetik aktivitedeki inhibisyon ile ilişkili olduğu bildirilmiştir (Khodadadi vd., 2017).

RuBisCO'nun yan1 sira karbon indirgenme reaksiyonlarında fonksiyon gören fruktoz-1,6bifosfat aldolaz, gliseraldehit-3-fosfat dehidrogenaz, sedoheptuloz-1,7-bifosfataz ve fosforibulokinaz gibi birçok enzimin ifade seviyelerindeki azalmalar kuraklık stresi altındaki birçok bitki türünde belirlenmiştir (Wang vd., 2017; Michaletti vd., 2018; Xin vd., 2018). Diğer taraftan, Calvin döngüsü enzimlerinin kuraklığa toleranslı yerfıstı̆̆ 1 yapraklarında arttığı, hassas varyete de ise azaldığı ve düşük bolluktaki bu proteinlerin oksidatif strese neden olarak fotosentetik aygitlara zarar verdiği belirtilmiştir (Katam vd., 2016).

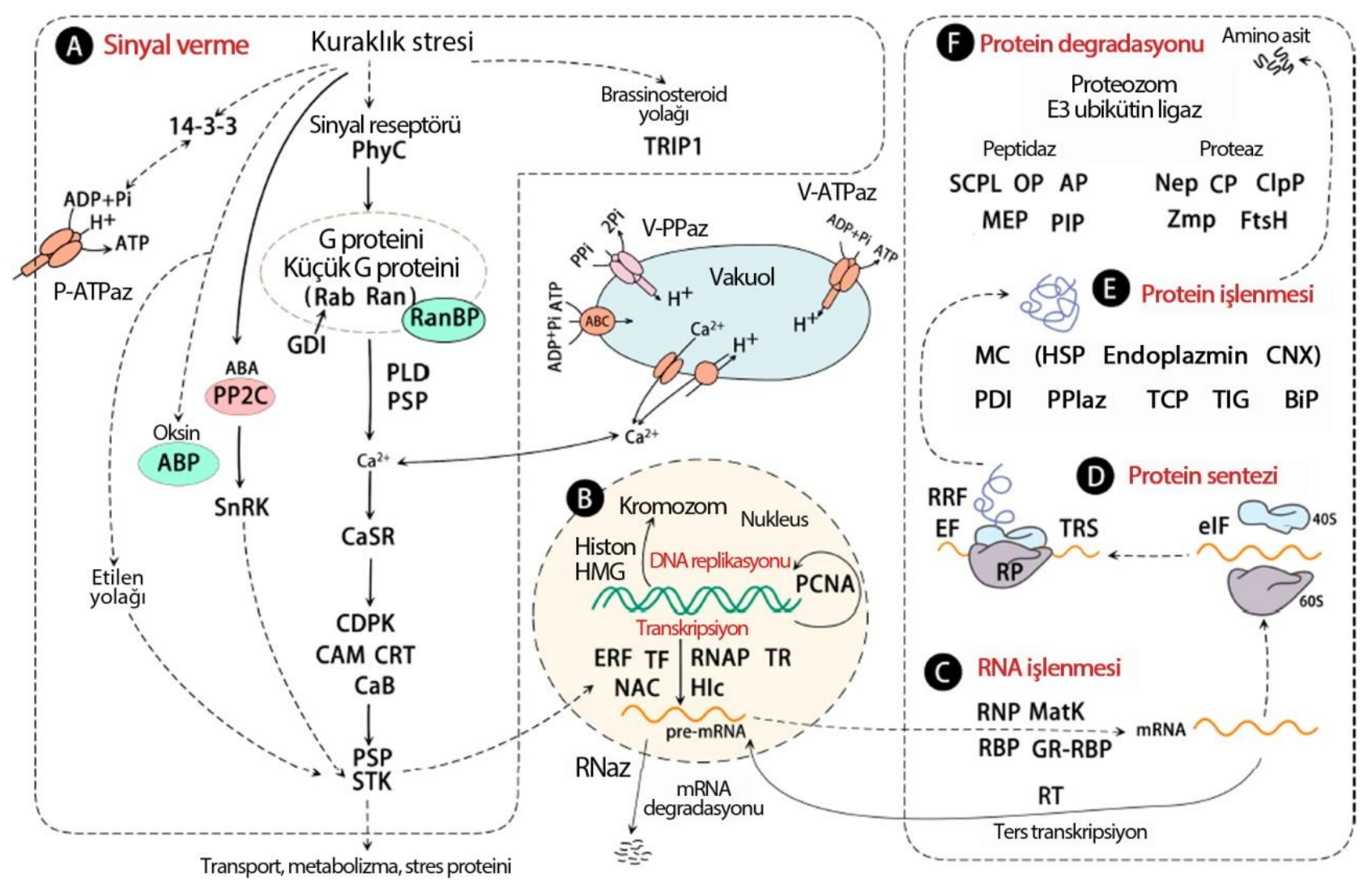

Şekil 1. Kuraklığa duyarlı proteinlerin sinyalleme, gen ifadesinin düzenlenmesi, protein sentezi ve parçalanması ile ilgili şematik gösterimi. Kesintisiz çizgi tek aşamalı reaksiyonları, kesikli çizgi reaksiyonun ara basamakların belirtir. (A) Sinyalleme; (B) DNA replikasyonu ve transkripsiyonu; (C) RNA işleme; (D) Protein sentezi; (E) Protein işleme; (F) Protein parçalanması. 14-3-3: 14-3-3 proteini; Nep: aspartik proteinaz; ClpP: ATP bağımlı Clp proteaz; ABP: oksin bağlayıcı protein; BiP: endoplasmik retikulumlüminal bağlayıcı protein; $\mathrm{CaB}$ : kalsiyum iyonu bağlayıcı protein; CaSR: kalsiyum algılama reseptörü; CDPK: kalsiyum bağımlı protein kinazı; CAM: kalmodulin; CNX: kalneksin; CRT: kalretikulin; CP: sistein proteinaz; EF: uzama faktörü; ERF: etilen ile tepki veren transkripsiyon faktörü; GDI: GDP ayrışma önleyicisi; GR-RBP: glisin bakımından zengin RNA bağlayıcı protein; HSP: 1sı şoku proteini; HMG: yüksek mobilite grup proteini; HOP: Hsp70-Hsp90 organize edici protein; AP: lösin aminopeptidaz; MatK: maturaz K; MEP: metalloendopeptidaz; MC: moleküler koruyucu; OP: oligopeptidaz A-benzeri; PPIaz: peptidilprolil cis-trans izomeraz; PLD: fosfolipaz D; PhyC: fitokrom C; PCNA: çoğalan hücre nükleer antijen; PIP: prolin iminopeptidaz; PDI: protein disülfür izomeraz; PP2C: protein fosfataz 2C; RanBP: Ran-bağlayıc1 protein; RT: retrotranspozon protein; RNaz: ribonükleaz; RNP: ribonükleoprotein; RP: ribozomal protein; RBP: RNA bağlayıcı protein; Hlc: RNA helikaz; RNAP: RNA polimeraz; SCPL: serin karboksipeptidaz benzeri protein; STK: serin/treonin kinaz; PSP: serin/treonin-protein fosfataz; SnRK: sükroz fermentasyon önleyici 1 protein kinaz; TCP: T kompleksi proteini; TRIP1: TGF- $\beta$ reseptör etkileşen protein 1; TF: transkripsiyon faktörü; TR: transkripsiyon regülatörü; TIG: tetikleyici faktör benzeri protein; V-PPaz: vakuolar $\mathrm{H}^{+}$-pirofosfataz; V-ATPaz: vakuolar $\mathrm{H}^{+}$-ATPaz; Zmp: çinko metaloproteazı (Wang vd., 2016'dan değiştirilerek). 
Ribuloz-1,5-bifosfatın yenilenmesinde fonksiyon gören enzim olan fosforibulokinaz enziminin kuraklığa hassas şeker pancarı (Beta vulgaris $\mathrm{L}$.) yapraklarında azalan yönde düzenlendiği bildirilmiştir (Wang vd., 2017). Bununla birlikte, RuBisCO'nun aktif bölgesinden inhibitör şeker fosfatın uzaklaştırılmasından sorumlu ATP bağımlı bir enzim olan RuBisCO aktivaz da kuraklık stresi tarafindan azalan yönde düzenlenmektedir (Kausar vd., 2013). Kuraklık stresi altında stoma kapanmasına bağlı olarak hücre içi $\mathrm{CO}_{2}$ konsantrasyonunun azalması ribuloz-1,5-bifosfatın oksijenasyonunu ve dolayısıyla fotorespirasyonu arttırmaktadır. Bununla birlikte, kuraklık stresi koşullarında fotorespirasyon ile ilişkili proteinlerin artan yönde düzenlenmesi fotorespirasyonun su stresi tarafından düzenlendiğini göstermektedir. Fotorespirasyon, zarar görmüş FSII'nin onarılmasında önemli olan D1 proteininin sentezinin inhibe olmasını önleyebilmektedir (Takahashi vd., 2007).

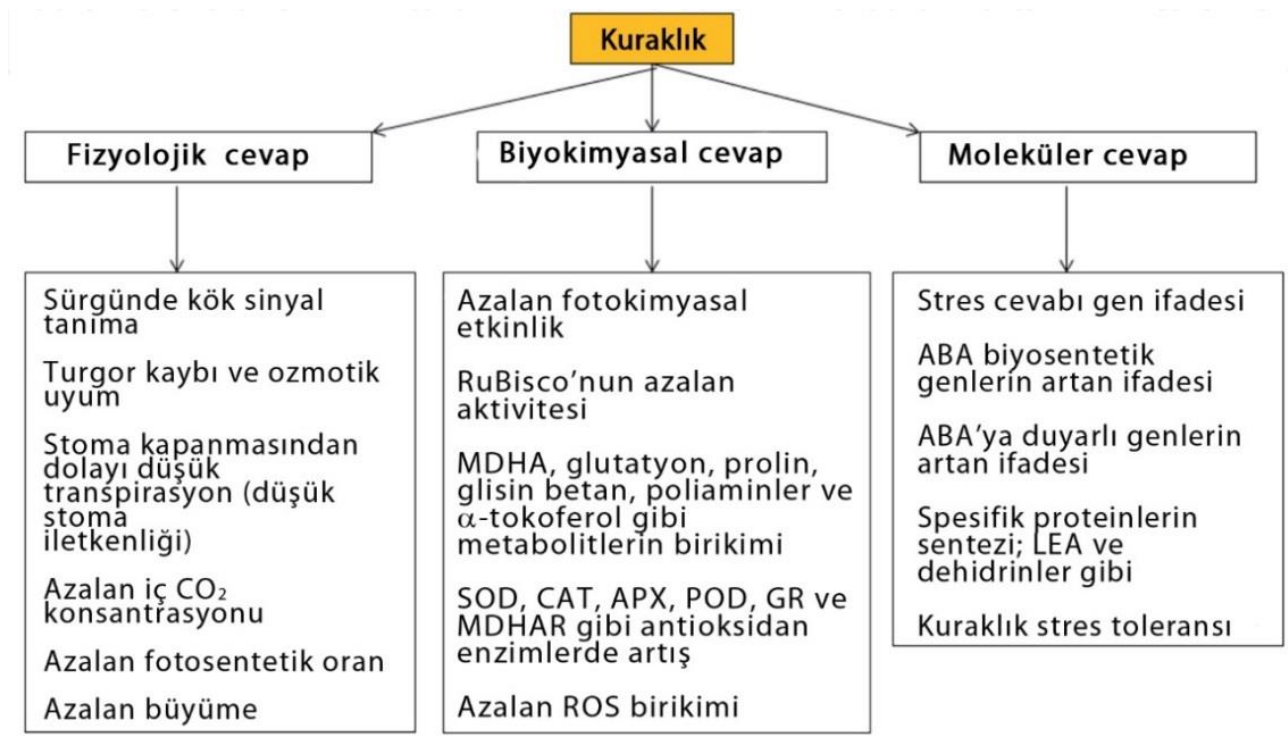

Şekil 2. Bitkilerde kuraklık stresi toleransının fizyolojik, biyokimyasal ve moleküler temelleri (Onaga ve Wydra 2017'den değiştirilerek).

Kuraklık stresinin fotoinhibisyona neden olarak fotosentezin biyokimyasal reaksiyonlarını sınırladığı (Johnová vd., 2016) ve fotosistemlerin zarar görmesinin ATP ve indirgeyici molekülerin oluşma kapasitesini azalttığı bildirilmiştir. Işı1k yakalama kompleksi, fotosistem II'nin kararlılı̆̆ını sağlayan önemli proteinlerin (CYP38 ve HCF136) ve bazı ATP sentaz altbirimlerinin kuraklık stresi altındaki bitki türlerinde azalan yönde düzenlendiği bildirilmiştir (Khodadadi vd., 2017; Michaletti vd., 2018). Diğer taraftan, FSII'nin reaksiyon merkezinde suyun parçalanmasından sorumlu bir protein olan OEE2 (oxygen-evolving enhancer 2) proteininin kuraklık toleranslı şeker pancarı yapraklarında artan yönde düzenlendiği bildirilmiştir (Wang vd., 2017). Gliserat-3-fosfat, NADPH molekülünden elektronlar1 alarak FSII'nin reaktif oksijen türlerine karşı korunmasını sağlamaktadır. Gliserat-3-fosfat dehidrogenaz proteinin kuraklığa toleranslı çeltik çeşidinde artan yönde düzenlendiği ve FSII'nin korunmasında bu enzimin bir role sahip olduğu bildirilmiştir (Chintakovid vd., 2017). LHCB (light-harvesting chlorophyll a/b-binding proteins) ailesine ait proteinlerin azalan yönde düzenlenmesinin stoma bekçi hücrelerinin ABA'ya karşı olan hassasiyetini azalttı̆g 1 ve bu durumun kuraklık toleransında azalmaya neden olduğu bildirilmiştir (Xu vd., 2012; Urban vd., 2017). Ayrica tiyoredoksin, demir-kükürt proteini, ferredoksinNADP redüktaz ve NADH dehidrogenaz gibi proteinleri kuraklık stresi koşullarında azalmasinin FSII ve FSI arasinda elektron transferini baskıladığı belirtilmiştir (Xin vd., 2018).

\subsection{Karbohidrat ve Enerji Metabolizmast ile İlişkili Proteinler}

Yeterli miktarda enerjinin ve dengeli karbohidrat üretiminin sürdürülmesi tüm bitkilerde en önemli olaylardır. Şekerler, enerjik fonksiyona hizmet etmenin yanı sıra birçok hücresel süreçte merkezi bir düzenleyici rol oynarlar ve bitki metabolizmasını ve gelişimini düzenleyen önemli sinyaller olarak kabul edilirler (Bilal vd., 2014). ATP metabolizması ile ilgili birçok enzimin 
kuraklık stresi koşullarında farklı şekilde ifade olduğu belirlenmiştir (Vítámvás vd., 2015). ATP sentaz alt birimlerindeki artışlar ile ilgili çalışmalarda belirtildiği gibi, bitki stres tepkilerini hedef alan birçok proteomik çalışmada, evrensel bir enerji kaynağı olarak ATP'ye duyulan ihtiyaç bildirilmiştir (Vítámvás vd., 2012; Kausar vd., 2013; Michaletti vd., 2018).

Glikoliz, trikarboksilik asit döngüsü ve pentoz fosfat yolağı gibi enerji metabolizması ile ilişkili birçok proteinin ekspresyon düzeyi kuraklık stresi koşullarında azaldığ 1 bilinmektedir (Xin vd., 2018). Fosfoglukomutaz karbohidrat metabolizmasında önemli bir enzimdir ve glukoz1-fosfatın glukoz-6-fosfata dönüşümünü kataliz etmektedir. Fosfoglukomutaz proteinin azalan yönde düzenlenmesinin, stres hasarını hafifletmek için gerekli olan enerjiyi azalttığ kuraklık stresi koşullarında koruyucu bir rol oynadığı bildirilmiştir (Zhang vd., 2009). Malatın oksaloasetata dönüşümünü kataliz eden malat dehidrogenaz trikarboksilik asit döngüsünün önemli bir enzimidir. Malat dehidrogenaz protein bolluğunun kuraklığa toleranslı şeker pancarı yapraklarında arttığı bildirilmiştir (Wang vd., 2017). Fosfogliserat kinaz glikoliz sirasında ATP üretiminde ve Calvin döngüsünde 1,3bifosfogliseratın oluşumunda önemli rol oynamaktadır (Joshi vd., 2016). Fosfogliserat kinaz proteinin ifade seviyesinin kuraklığa toleranslı rezene genotipinde $\operatorname{arttığ}$, buna karşın hassas genotipte azaldı ğı bildirilmiştir (Khodadadi vd., 2017). Fruktoz-bifosfat aldolaz; fruktoz-1,6bifosfatın gliseraldehit-3-fosfata ve dihidroksiaseton fosfata dönüşmesini kataliz etmektedir. $\mathrm{Bu}$ proteinin bolluğundaki azalma kuraklık stresi altındaki kolza ve arpa gibi bitki türlerinde belirlenmiştir (Vitamvas vd., 2015; Urban vd., 2017). Glikolizde fonksiyon gören iki enzim olan enolaz ve fruktoz-1,6-bifosfat aldolazın kuraklık stresi altındaki buğday bitkilerinde azaldığı bildirilmiştir (Zhang vd., 2014). Sonuç olarak, kuraklık stresi koşullarında fotosentezin engellenmesine bağlı olarak bitkilerin karbonhidrat metabolizmasinın olumsuz etkilendiği ve enerji tüketiminin azaldığı iyi bilinmektedir (Kosova vd., 2011). Bu sonuçlar, bitkilerde kuraklığa toleransin fotosentez ve enerji metabolizmasının düzenlenmesi ile ilişkili olabileceğini göstermektedir.

\subsection{Antioksidan Savunma ile İlişkili Proteinler}

Kuraklık gibi çevresel stresler, fotosentez, mitokondriyal solunum ve fotorespirasyon gibi süreçlere zarar vermekte ve reaktif oksijen türlerinin üretimini artırmaktadır (Mittler, 2002). Normal koşullarda bitkiler reaktif oksijen türlerini programlanmış hücre ölümü, abiyotik stres cevapları ve patojenlere karşı savunma gibi çeşitli hücresel olaylarda sinyal molekülü olarak kullanmaktadır. Strese maruz kalan bitkilerde aşırı üretilen reaktif oksijen türleri lipitler, nükleik asitler ve proteinlerde oksidatif zarara neden olarak hücre ölümüne yol açmaktadır (Pitzschke vd., 2006). Reaktif oksijen türlerinin seviyelerini korumak için enzimatik ve enzimatik olmayan mekanizmaların kompleks dizilerini gelişmiştir. Kuraklık stresine maruz kalan birçok bitki türünde süperoksit dismutaz (SOD), askorbat peroksidaz (APX), katalaz (CAT), peroksidaz (POD), tiyoredoksin peroksidaz, glutatyon S-transferaz (GST) gibi enzimlerin protein bolluklarının değişiklik gösterdiği bildirilmiştir (Faghani vd., 2015; Li vd., 2018; Xin vd., 2018). SOD, yüksek derecede toksik süperoksit anyonunu daha az toksik hidrojen peroksite dönüştürerek oksidatif hasara karş1 ilk savunma hattı olarak bilinmektedir. SOD proteinin ifade seviyesindeki artış kuraklık stresi altındaki çeltik ve buğday gibi bitki türlerinde belirlenmiştir (Ji vd., 2012; Faghani vd., 2015). SOD enziminin abiyotik streslere tolerans kazandırılmasındaki önemi, bu enzimi kodlayan genleri aşırı ifade eden transgenik bitkiler kullanılarak ortaya çıkarılmıştır (Faize vd., 2011; Negi vd., 2015). Artan APX ifade seviyesi kuraklık stresi altındaki birçok bitki türünde belirlenmiş (Chmielewska vd., 2016; Wang vd., 2017) ve kuraklık stresi koşullarında artan askorbat-glutatyon döngüsü aktivitesinin toleranslı genotiplerde daha belirgin olduğu bildirilmiştir (Chmielewska vd., 2016; Wang vd., 2017). GST, tripeptid glutatyon ile ksenobiyotiklerin detoksifikasyonunda rol oynayan ve oksidatif stresi hafifleten önemli bir enzimdir (Marrs, 1996). Kuraklığa hassas buğday genotipinde GST ifadesinin azalan yönde düzenlendiği ve bu genotipin toksik molekülleri detoksifiye etmede başarısız olduğu bildirilmiştir (Michaletti vd., 2018). Benzer olarak, GST bolluğundaki artışın sadece kuraklığa toleranslı arpa genotiplerinde olduğu bildirilmiştir (Kausar vd., 2013; Chmielewska vd., 2016). Bununla birlikte, domates GST genini aşırı ifade eden transgenik Arabidopsis bitkilerinde kuraklık toleransının arttığı rapor edilmiştir (Xu vd., 2015).

Peroksiredoksinlerin (Prx), farklı türde biyotik ve abiyotik streslere maruz kalan bitkilerde elektron taşıma aktiviteleri sonucu üretilen reaktif oksijen türleriyle mücadelede önemli bir rol oynadığ 1 bilinmektedir. Prx'lerin gelişim ve adaptasyon sırasında redoks sinyalini düzenlediği ve DNA 
hasarlarına karşı koruma sağladığı gösterilmiştir (Tripathi vd., 2009). Reaktif oksijen türlerini indirgeyen peroksidazlarm bir grubu olan 2-Cys Prx sülfidril rezidüelerinden peroksitlere elektronların transferini kataliz etmektedir. Prx2E, tiyoredoksin sistemi aracillğıyla sağlanan detoksifikasyonda yer alır ve kloroplast redoks homeostazında rol oynayabilir (Baier ve Dietz, 1997). Farklı Prx proteinlerin kuraklık stresi altındaki bazı bitki türlerinde artan yönde düzenlendiği bildirilmiştir (Zhang vd., 2016; Urban vd., 2017; Xin vd., 2018). Sonuç olarak, bitki hücrelerinde kuraklık stresine karşı antioksidanların yüksek düzeyde ifade edilmesi, bitkilerin kuraklık toleransında önemli rol oynayabilir.

\subsection{Protein Metabolizması İle İlişskili Proteinler}

Moleküler şaperonlar olarak bilinen sıcaklık şoku protein (heat shock protein, HSP) ailesi, normal bitki büyüme süreçlerini düzenlemede rol oynamaktadır. Stres koşullarında reaktif oksijen türleri HSP70 üretimi ve birikiminin düzenlenmesine katılır (Piterkova vd., 2013). Birkaç şaperon kompleksi (HSP90) dokuya özgü ABA yantlarının düzenlenmesinde fonksiyon görebilmektedir (Clement vd., 2011). Protein katlanması için önemli bir moleküler şaperon olan HSP70, hücrelerin strese karşı korunmasına yardımcı olmaktadır. Tuzluluk, soğuk ve kuraklık gibi birçok abiyotik stres altında ekspresyon seviyelerini arttırdığ 2013). HSP70'in artan yönde düzenlenmesi, hasarlı proteinlerin hizlı bozunması ve reaktivasyonu yoluyla korunmasinı ve böylece kuraklık stresine toleransı artırmaya yardımc1 olduğunu göstermektedir (Mohammadi vd., 2012; Xin vd., 2018). Kloroplastik HSP70 proteininin ifade seviyesinin kuraklığa toleranslı şeker pancarı yapraklarında arttığı buna karşın hassas genotipte azaldığı bildirilmiştir. $\mathrm{Bu}$ durumun, kuraklığa toleranslı genotipte kloroplastik HSP70'in ifade seviyesinin artmasının, FSII ve diğer önemli hücresel bileşenleri kuraklık stresi altındaki hasardan koruyabileceğini gösterdiği bildirilmiştir (Wang vd., 2017). Bununla birlikte, HSP70, şaperonin 60, protein disülfit izomeraz, şaperonin 21 ve siklofilin gibi protein metabolizması ile ilgili proteinlerin kuraklığa toleranslı yer fistığ genotipinde artan yönde düzenlediği, hassas genotipte ise azalan yönde düzenlendiği bildirilmiştir (Katam vd., 2016).

HSP90 hücrelerde oldukça fazla miktarda bulunan bir proteindir ve toplam hücresel proteinin yaklaşık \%1-2'sini oluşturmaktadır (Frydman,
2001). HSP90 protein katlanmasının yanı sira sinyal iletimi, hücre döngüsünün kontrolü, protein degredasyonu ve protein trafiğinde fonksiyon görmektedir (Wang vd., 2004). HSP90'in ifade seviyesinin birçok stres koşulunda artmakta ve Arabidopsis'in kuraklık toleransinda rol oynayabileceği bildirilmiştir (Song vd., 2009). ATP bağımlı Clp proteazlar (HSP100) moleküler şaperonlar olarak işlevlerine ek olarak, yanlış katlanmış proteinlerin degredasyonunu sağlayarak hücresel homeostazın sürdürülmesinde rol oynamaktadır. Aşırı kuraklık stresine maruz bırakılan buğday fidelerinde $\mathrm{Clp}$ proteaz proteininin arttı̆g 1 bildirilmiştir (Larkindale ve Vierling, 2008). Bu bağlamda, birçok stres koşulunda HSP'lerin protein metabolizmasında önemli rol oynadığ 1 ve bu nedenle kuraklık toleransı ile yakından ilişkili olduğu ileri sürülebilir.

\subsection{Sinyal İletimi İle İlişskili Proteinler}

Bitkiler strese maruz kaldığında, genellikle stres sinyalleri özel reseptörler aracillğıyla algilanmakta ve daha sonra gen ifadesini düzenlemek için bu sinyaller sinyal iletim mekanizmasına gönderilmektedir (Yan vd., 2006). Protein fosfataz 2C (PP2C), absisik asit ve gibberellik asit gibi bitki hormonlarının yanı sıra kuraklık, tuz, yaralanma ve soğuk gibi çeşitli stresler tarafindan aktive edilen sinyal yolaklarının genel bir düzenleyicisi olarak işlev görmektedir (Liu vd., 2009). Kuraklık stresi altındaki misir fidelerinde PP2C proteininin azaldığ 1 ve PP2C'nin kısa süreli kuraklık stresine karşı savunma için sinyal yollarının düzenlenmesine katkıda bulunduğunu ileri sürülmüştür (Xin vd., 2018). Yüksek oranda korunmuş asidik 14-3-3 protein ailesi sinyal iletimi ve apoptoz olmak üzere birçok fizyolojik süreçte 200 'den fazla hedef protein ile etkileşime girebilmektedir (Mhawech, 2005; Sun vd., 2011). 14-3-3 proteininin kuraklık stresine toleransl buğday genotipinde artan yönde düzenlendiği bildirilmiştir (Hao vd., 2015). Diğer taraftan, 143-3 proteininin hassas buğday genotipinde kuraklık stresine cevap olarak azaldığ 1 bildirilmiştir (Faghani vd., 2015). Shi vd. (2014), sinyal iletiminde yer alan 14-3-3 benzeri proteininin kuraklık stresi yanıtında önemli bir rol oynayabileceğini bildirmiştir. Ayrıca Arabidopsis 14-3-3 proteinini kodlayan geni aşırı ifade eden pamuk bitkilerinde kuraklık toleransının arttığı rapor edilmiştir (Yan vd., 2004). Sitoplazmik $\mathrm{Ca}^{+2}$ bağlayıcı bir protein olan TCTP (translationally controlled tumor protein)'nin ifade seviyesinin kuraklık stresine yanıt olarak buğday fidelerinde 
arttığı belirtilmiştir (Zhang vd., 2014). TCTP'nin strese maruz kalan bitki hücrelerinde $\mathrm{Ca}^{+2}$ homeostazının korunmasinda rol oynaması mümkündür, çünkü biyotik ve abiyotik stres gibi hücre dış1 sinyaller, bitkilerde $\mathrm{Ca}^{+2}$ hücresi konsantrasyonundaki değişikliklere yol açabilmektedir (Luan vd., 2002). Sinyal iletiminde fonksiyon gören diğer bir protein olan anneksinlerin bitkilerin tuz ve kuraklık stresi ile ilişskili olabileceği bildirilmiştir (KonopkaPostupolska vd., 2009; Sobhanian vd., 2010). Zit olarak, anneksin proteininin kuraklığa hassas fasulye (Phaseolus vulgaris L.) bitkilerinde artan yönde düzenlendiği ve anneksin proteininin kuraklık toleransı ile ilişkili olmadığı bildirilmiştir (Zadražnika vd., 2013). Kuraklık stresine tolerans ile ilişkili olarak sinyalin algılanması ve iletiminin anlaşılması bakımından yeterli çalışma bulunmamaktadır. Kuraklık stresi yanıtlarının genom ve proteom düzeyindeki analizleri, kuraklık stresi sinyal ağlarına 1 şı tutabilir ve kuraklık toleransı mekanizmalarının aydınlatılmasında önemli veriler sağlayabilir.

\subsection{Kuraklık Stresi İle İlişkili Diğer Proteinler}

Kuraklık dahil olmak üzere birçok çevresel stres, muhtemelen elektron taşıma zincirinin azalmasına bağlı olarak bitki hücrelerinde serbest amino asit ve aminlerin artmasina neden olmaktadır (Reggiani vd., 2000). Bu amino asitler ve aminler ozmoprotektan, ozmotik düzenleyici veya reaktif oksijen türlerinin temizleyicileri olarak işlev görebilmektedir. Prolin ve glisin betain (GB) gibi ozmoprotektanlarm sentezinde rol oynayan proteinlerin düzenlemesi bitkilerin stres toleransında önemli bir rol oynamaktadır (Alam vd., 2010). Glutamin sentetaz (GS) azot metabolizmasında önemli bir rol oynamakta ve bitkilerde prolin seviyesinin düzenlenmesinde fonksiyon gördüğü belirtilmiştir. Kuraklık stresi altındaki soya fasulyesinde GS proteinin artan bolluğunun yüksek prolin içeriği ile ilişkili olduğu ileri sürülmüştür (Alam vd., 2010). Glisin betain önemli bir osmoprotektandır ve iki aşamalı bir kolin oksidasyonu ile sentezlenmektedir. Kolin monooksijenaz (CMO), GB sentezi için hız sınırlayıcı bir basamak olarak düşünülen reaksiyonun ilk adımını katalize etmektedir (Luo vd., 2012). Kuraklığa hassas şeker pancarı genotipinde CMO proteininin seviyesinin azalmasinın ve toleranslı genotipte bu proteinin seviyesindeki artışın, bu iki genotipin farklı tolerans seviyelerini açılayabileceği ileri sürülmüştür (Wang vd., 2017). Bununla birlikte, şeker pancarı CMO genini plastidlerinde aşırı ifade eden tütün bitkilerinde tuz ve kuraklık toleransının arttı̆̆ bildirilmiştir (Zhang vd., 2008).

LEA (Late-embryogenesis abundant) proteinleri, desikasyona toleranslı bitkilerde yüksek konsantrasyonda sentezlenen suda çözünebilir proteinlerdir (Alam vd., 2010). Kuraklık stresi altındaki soya fasulyesi bitkilerinde dehidrin ve ferritin proteinlerinin artan yönde düzenlendiği belirtilmiştir (Alam vd., 2010). Dehidrinler LEA proteinleridir ve reaktif oksijen türlerinin zararlı etkilerini azaltarak stres altında bitki gelişimini etkili bir şekilde arttırabilmektedirler (Hossain vd., 2013). Medicago truncatula bitkilerinde tespit edilen birçok proteinin LEA proteini olduğu ve bu proteinlerin kuraklık toleransı ile ilişkili olduğu rapor edilmiştir (Boudet vd., 2006).

Kuraklık stresi altındaki bitkilerde amino asit metabolizması ile ilişkili birçok proteinin ifade seviyesinin farklı şekilde düzenlendiği bildirilmiştir (Khodadadi vd., 2017; Xin vd., 2018). Kuraklık stresi altındaki rezene bitkilerinde S-adenozil metiyonin sentezinden sorumlu bir enzim olan kobalamin bağımsız metiyonin sentaz protein bolluğunun hassas genotipte azaldığı, toleranslı genotipte ise arttığı bildirilmiştir (Khodadadi vd., 2017). Metiyonin sentaz, 5metiltetrahidrofolattan bir metil grubunun homosisteine transferini katalize etmekte ve böylelikle etilen ve poliaminlerin öncüsü metiyonin sentezlenmektedir (González vd., 1992). Metiyonin sentaz ve kobalamin-bağımsız metiyonin sentaz enzimindeki artışlar, bitkilerin kuraklık stresinin üstesinden gelmeleri için metiyonin ve ozmotik düzenleyicilerin metabolizmasını artırabileceğini göstermektedir (Khodadadi vd., 2017). Bununla birlikte, metiyonin sentaz ve metil transferazlar lignin monomerlerinin biyosentezinde aktif metil grupları sağlamakta ve böylece hücre duvarı bileşenlerini güçlendirmekte ve stres sirasinda bütünlüklerini korumaktadır (Ravanel vd., 2004). Metiyonin sentaz bolluğunun kuraklığa toleranslı yer fistığı genotipinde daha fazla olduğu bildirilmiştir (Katam vd., 2016). Aspartat aminotransferaz amino asit sentezinde önemli bir enzimdir ve karbon ve azot metabolizmasının düzenlenmesinde önemli rol oynamaktadır (Zhou vd., 2009). $\mathrm{Bu}$ enzimin azalan yönde düzenlenmesinin misır fidelerinde amino asit sentezini olumsuz etkileyebileceği ileri sürülmüştür (Meyer vd., 2014; Xin vd., 2018). Alanin-2-oksoglutarat aminotransferaz (AlaAT), L-alanin ve 2-oksoglutarat arasindaki transaminasyon reaksiyonunu ve L-glutamat ve pirüvat arasındaki ters reaksiyonu kataliz 
etmektedir. Bu enzim azot metabolizmasında ve yapraklardaki serin, sitrülin ve glisin içeriğinin düzenlenmesinde çok önemli bir rol oynamaktadır (Rocha vd., 2010). Kuraklığa bağlı ATP eksikliğinde, alanin ve glutamat yolaklarının düzenlenmesiyle ATP'ye bağımlı enzim olan GS ile AlaAT yer değiştirmesine izin vermektedir (Limami vd., 2008). Bu adaptasyon ATP'yi korur, $\mathrm{NAD}(+)^{\prime} 1$ yeniden üretir ve karbonu alanin formunda saklar. AlaAT'nin bolluğundaki azalmanın, ATP'ye bağımlı hemen hemen tüm proteinlerin genel olarak düşük bolluğu ile ilişkili olduğu belirtilmiştir (Urban vd., 2017).

\section{Sonuç}

Kuraklık stresi, tarımsal alanların kullanılabilirliği ve kalitesini olumsuz etkilemesinin yanı sira bitkiler üzerinde fizyolojik, biyokimyasal ve moleküler düzeyde olumsuz etkiler oluşturmaktadır. Kuraklık stresine cevap olarak metabolik değişimler, kuraklık toleransında rol oynayan proteinler ve onları kodlayan genlerin belirlenmesinin yanı sira stres sinyal yolaklarının aydınlatılması ıslah çalışmaları için önemli veriler sağlayacaktır. Proteomik, kuraklık stresi altındaki bitkilerde karmaşık sinyal ve metabolik ağları daha iyi anlamak için önemli bilgilerin elde edilmesini sağlamıştır. Günümüze kadar yapılmış olan proteomik çalışmaların çoğu kuraklık stresinin algılanması ve sinyal iletimi, reaktif oksijen türlerinin temizlenmesi, protein metabolizması, hücre yapısının modülasyonu ve enerji metabolizması ile ilişkili birçok aday proteinin belirlenmesini sağlamıştır. Proteomik analizler ve translasyon sonrası modifikasyonların karakterizasyonu ile birlikte genomik bilgilerin kullanımı, yeni aday proteinlerin keşfedilmesini ve tolerans ile ilişskili dinamiklerin anlaşılmasını kolaylaştıracaktır. Sonuç olarak, gelecekte proteom analiz teknolojilerinin geliştirilmesiyle birlikte kuraklık stresine cevapta önemli rolleri olan translasyon sonras1 protein modifikasyonlar1, protein-protein etkileşimleri ve moleküler ağların daha iyi anlaşılması, kurak bölgelerde kolaylıkla yetişebilecek yeni bitki genotiplerinin geliştirilmesine katkı sağlayacaktır.

\section{Kaynaklar}

Abreu, I., Farinha, A., Negrao, S., Goncalves, N., Fonseca, C., Rodrigues, M., Batista, R., Saibo, N. ve Oliveira, M., 2013. Coping with abiotic stress, proteome changes for crop improvement. Journal of Proteomics, 93, 145-168.

Alam, I., Sharmin, S. A., Kim, K., Yang, J. K., Choi, M. S. ve Lee, B., 2010. Proteome analysis of soybean roots subjected to short-term drought stress. Plant and Soil, 333, 491-505.

Babita, M., Maheswari, M., RaoL, M., Shanker, A.K. ve Rao, D.G., 2010. Osmotic adjustment, drought tolerance and yield in castor (Ricinus communis L.) hybrids. Environmental and Experimental Botany, 69, 243-249.

Baier, M. ve Dietz, K.J., 1997. The plant 2-Cys peroxiredoxin BAS1 is a nuclear-encoded chloroplast protein: its expressional regulation, phylogenetic origin, and implications for its specific physiological function in plants. The Plant Journal, 12, 179-190.

Baldoni, E., Genga, A. ve Cominelli, E., 2015. Plant MYB transcription factors: their role in drought response mechanisms. International Journal of Molecular Sciences, 16, 15811-15851.

Barkla, B.J., Vera-Estrella, R. ve Raymond, C., 2016. Single-cell-type quantitative proteomic and ionomic analysis of epidermal bladder cells from the halophyte model plant Mesembryanthemum crystallinum to identify salt-responsive proteins. BMC Plant Biology, 16,110 .

Batlang, U., Baisakh, N., Ambavaram, M.M. ve Pereira, A., 2013. Phenotypic and physiological evaluation for drought and salinity stress responses in rice. Methods in Molecular Biology, 956, 209-225.

Bilal, T., Bisma, P. ve Reiaz, M., 2014. Signaling in response to cold stress, in: I. Tahir, R.U. Rehman, K.R. Hakeem (Eds.), Plant Signaling: Understanding the Molecular Crosstalk, Springer India, pp. 193-226.

Boudet, J., Buitink, J., Hoekstra, F. A., Rogniaux, H., Larré, C. ve Satour, P., 2006. Comparative analysis of the heat stable proteome of radicles of Medicago truncatula seeds during germination identifies late embryogenesis abundant proteins associated with desiccation tolerance. Plant Physiology, 140, 1418-1436.

Chaves, M.M., Flexas, J. ve Pinheiro, C., 2009. Photosynthesis under drought and salt stress: regulation mechanisms from whole plant to cell. Annals of Botany, 103, 551-560.

Chen, F., Zhang, S., Jiang, H., Ma, W., Korpelainen, H. ve $\mathrm{Li}, \mathrm{C} .$, 2011. Comparative proteomics analysis of salt response reveals sex-related photosynthetic inhibition by salinity in Populus cathayana cuttings. Journal of Proteome Research, 10(9), 3944-3958.

Chintakovid, N., Maipoka, M., Phaonakrop, N., Mickelbart, M.V., Roytrakul, S. ve Chadchawan, S., 2017. Proteomic analysis of 
drought-responsive proteins in rice reveals photosynthesis-related adaptations to drought stress. Acta Physiologiae Plantarum, 39(10), 113.

Chmielewska, K., Rodziewicz, P., Swarcewicz, B., Sawikowska, A., Krajewski, P., Marczak, Ł., Ciesiołka, D., Kuczynska, A., Mikołajczak, K., Ogrodowicz, P., Krystkowiak, K., Surma, M., Adamski, T., Bednarek, P. ve Stobiecki, M., 2016. Analysis of drought-induced proteomic and metabolomic changes in barley (Hordeum vulgare L.) leaves and roots unravels some aspects of biochemical mechanisms involved in drought tolerance. Frontiers in Plant Science, 7, $1-14$.

Clement, M., Leonhardt, N., Droillard, M. J. ve Reiter, I., 2011. The cytosolic/nuclear HSC70 and HSP90 molecular chaperones are important for stomatal closure and modulate abscisic aciddependent physiological responses in Arabidopsis. Plant Physiology, 156, 1481-1492.

Faghani, E., Gharechahi, J., Komatsu, S., Mirzaei, M., Khavarinejad, R.A., Najafi, F., Farsad, L.K. ve Salekdeh, G.H., 2015. Comparative physiology and proteomic analysis of two wheat genotypes contrasting in drought tolerance. Journal of Proteomics, 114, 1-15.

Faize, M., Burgos, L., Faize, L.V., Piqueras, A., Nicolas, E., Barba-Espin, G., Clemente-Moreno, M.J., Alcobendas, R., Artlip, T. ve Hernandez, J.A., 2011. Involvement of cytosolic ascorbate peroxidase and $\mathrm{Cu} / \mathrm{Zn}$-superoxide dismutase for improved tolerance against drought stress. Journal of Experimental Botany, 62, 25992613.

Frydman, J., 2001. Folding of newly translated proteins in vivo: the role of molecular chaperones. Annual Review of Biochemistry, 70, 603-647.

Gao, S., Zhang, Y.L., Yang, L., Song, J.B. ve Yang, Z.M., 2014. AtMYB20 is negatively involved in plant adaptive response to drought stress. Plant and Soil, 376, 433-443.

González, J.C., Banerjee, R.V., Huang, S., Sumner, J.S. ve Matthews, R.G., 1992. Comparison of cobalamin-independent and cobalamindependent methionine synthases from Escherichia coli: two solutions to the same chemical problem. Biochemistry, 31, 60456056.

Hao, P., Zhu, J., Gu, A., Lv, D., Ge, P. ve Chen, G., 2015. An integrative proteome analysis of different seedling organs in tolerant and sensitive wheat cultivars under drought stress and recovery. Proteomics, 15, 1544-1563.
Hossain, Z., Khatoon, A. ve Komatsu, S., 2013. Soybean proteomics for unraveling abiotic stress response mechanism. Journal of Proteome Research, 12, 4670-4684.

Ji, K., Wang, Y., Sun, W., Lou, Q., Mei, H. ve Shen, S., 2012. Drought-responsive mechanisms in rice genotypes with contrasting drought tolerance during reproductive stage. Journal of Plant Physiology, 169, 336-344.

Johnová, P., Skalák, J., Saiz-Fernández, I. ve Brzobohatý, B., 2016. Plant responses to ambient temperature fluctuations and waterlimiting conditions: a proteome-wide perspective. Biochimica et Biophysica Acta, 1864, 916-931.

Joshi, R., Karan, R., Singla-Pareek, S.L. ve Pareek, A., 2016. Ectopic expression of Pokkali phosphoglycerate kinase-2 (OsPGK2-P) improves yield in tobacco plants under salinity stress. Plant Cell Reports, 35, 27-41.

Katam, R., Sakata, K., Suravajhala, P., Pechan, T., Kambiranda, D.M., Naik, K.S. ve Basha, S.M., 2016. Comparative leaf proteomics of droughttolerant and -susceptible peanut in response to water stress. Journal of Proteomics, 143, 209226.

Kausar, R., Arshad, M., Shahzad, A. ve Komatsu, S., 2013. Proteomics analysis of sensitive and tolerant barley genotypes under drought stress. Amino Acids, 44, 345-359.

Khodadadi, E., Fakheri, B. A., Aharizad, S., Emamjomeh, A., Norouzi, M. ve Komatsu, S., 2017. Leaf proteomics of drought-sensitive and -tolerant genotypes of fennel. Biochimica et Biophysica Acta - Proteins and Proteomics, 1865(11), 1433-1444.

Komatsu, S., Makino, T. ve Yasue, H., 2013. Proteomic and biochemical analyses of the cotyledon and root of flooding-stressed soybean plants. PLoS ONE, 8, e65301.

Konopka-Postupolska, D., Clark, G., Goch, G., Debski, J., Floras, K. ve Cantero, A., 2009. The role of annexin 1 in drought stress in Arabidopsis. Plant Physiology, 150, 1394-410.

Kosma, D. K., Murmu, J., Razeq, F. M., Santos, P., Bourgault, R. ve Molina, I., 2014. AtMYB41 activates ectopic suberin synthesis and assembly in multiple plant species and cell types. The Plant Journal, 80, 216-229.

Kosova, K., Vitamvas, P., Prasil, I.T. ve Renaut, J., 2011. Plant proteome changes under abiotic stress - contribution of proteomics studies to understanding plant stress response. Journal of Proteomics, 74, 1301-1322. 
Kosová, K., Vítámvás, P., Urban, M.O., Prášil, I.T. ve Renaut, J., 2018. Plant abiotic stress proteomics: The major factors determining alterations in cellular proteome. Frontiers in Plant Science, 9, $1-22$.

Kumari, S., Roy, S., Singh, P., Singla-Pareek, S.L. ve Pareek, A., 2013. Cyclophilins: proteins in search of function. Plant Signaling and Behavior, 8(1), e22734.

Larkindale, J. ve Vierling, E., 2008. Core genome responses involved in acclimation to high temperature. Plant Physiology, 146, 748-761.

Li, J.W., Chen, X.D., Hu, X.Y., Ma, L. ve Zhang, S.B., 2018. Comparative physiological and proteomic analyses reveal different adaptive strategies by Cymbidium sinense and $C$. tracyanum to drought. Planta, 247(1), 69-97.

Limami, A.M., Glevarec, G., Ricoult, C., Cliquet, J.B. ve Planchet, E., 2008. Concerted modulation of alanine and glutamate metabolism in young Medicago truncatula seedlings under hypoxic stress. Journal of Experimental Botany, 59, 2325-2335.

Liu, L., Hu, X., Song, J., Zong, X., Li, D. ve Li, D., 2009. Over-expression of a Zea mays L. protein phosphatase 2C gene (ZmPP2C) in Arabidopsis thaliana decreases tolerance to salt and drought. Journal of Plant Physiology, 166, 531-542.

Luan, S., Kudla, J., Rodriguez-Concepcion, M., Yalovsky, S. ve Gruissem, W., 2002. Calmodulins and calcineurin B-like proteins: calcium sensors for specific signal response coupling in plants. Plant Cell, 14, 389-400.

Luo, D., Niu, X., Yu, J., Yan, J., Gou, X., Lu, B.R. ve Liu, Y., 2012. Rice choline monooxygenase (OsCMO) protein functions in enhancing glycine betaine biosynthesis in transgenic tobacco but does not accumulate in rice (Oryza sativa L. ssp. japonica). Plant Cell Reports, 31,1625-1635.

Marrs, K.A., 1996. The functions and regulation of glutathione S-transferases in plants. Annual Review of Plant Physiology and Plant Molecular Biology, 47, 127-158.

Meyer, E., Aspinwall, M.J., Lowry, D.B., PalacioMejia, J.D., Logan, T.L., Fay, P.A. ve Juenger, T.E., 2014. Integrating transcriptional, metabolomic, and physiological responses to drought stress and recovery in switchgrass (Panicum virgatum L.). BMC Genomics, 15, 527.

Mhawech, P., 2005. 14-3-3 proteins - an update. Cell Research, 15, 228-236.
Michaletti, A., Naghavi, M. R., Toorchi, M., Zolla, L. ve Rinalducci, S., 2018. Metabolomics and proteomics reveal drought-stress responses of leaf tissues from spring-wheat. Scientific Reports, 8(1), 1-18.

Mittler, R., 2002. Oxidative stress, antioxidants and stress tolerance. Trends in Plant Science, 7, 405-410.

Mohammadi, P.P., Moieni, A. ve Komatsu, S., 2012. Comparative proteome analysis of droughtsensitive and drought-tolerant rapeseed roots and their hybrid F1 line under drought stress. Amino Acids, 43, 2137-2152.

Moschen, S., Di Rienzo, J. A., Higgins, J., Tohge, T., Watanabe, M., González, S. ve Heinz, R. A., 2017. Integration of transcriptomic and metabolic data reveals hub transcription factors involved in drought stress response in sunflower (Helianthus annuus L.). Plant Molecular Biology, 94(4-5), 549-564.

Nakashima, K., Yamaguchi-Shinozaki, K. ve Shinozaki, K., 2014. The transcriptional regulatory network in the drought response and its crosstalk in abiotic stress responses including drought, cold, and heat. Frontiers in Plant Science, 5, 1-7.

Negi, N.P., Shrivastava, D.C., Sharma, V. ve Sarin, N.B., 2015. Overexpression of CuZnSOD from Arachis hypogaea alleviates salinity and drought stress in tobacco. Plant Cell Reports, 34(7), 1109-1126.

Nemati, N., Piro, A., Norouzi, M., Vaheda, M.M., Nisticò, D.M. ve Mazzuca, S., 2019. Comparative physiological and leaf proteomic analyses revealed the tolerant and sensitive traits to drought stress in two wheat parental lines and their F6 progenies. Environmental and Experimental Botany, 158, 223-237.

Onaga, G. ve Wydra, K., 2016. Advances in plant tolerance to abiotic stresses, in: Abdurakhmonov, I.Y. (Ed.), Plant Genomics, IntechOpen, pp. 167-228.

Piterkova, J., Luhova, L., Mieslerova, B., Lebeda, A. ve Petrivalsky, M., 2013. Nitric oxide and reactive oxygen species regulate the accumulation of heat shock proteins in tomato leaves in response to heat shock and pathogen infection. Plant Science, 207, 57-65.

Pitzschke, A., Forzani, C. ve Hirt, H., 2006. Reactive oxygen species signaling in plants. Antioxidants and Redox Signaling, 8, 1757-1764.

Prasad, P.V.V., Pisipati, S.R., Momčilović, I. ve Ristic, Z., 2011. Independent and combined effects of high temperature and drought stress during 
grain filling on plant yield and chloroplast EF$\mathrm{Tu}$ expression in spring wheat. Journal of Agronomy and Crop Science, 197, 430-441.

Rasheed, S., Bashir, K., Matsui, A., Iida, K., Tanaka, M. ve Seki, M., 2016. Transcriptomic analysis of soil-grown Arabidopsis thaliana roots and shoots in response to a drought stress. Frontiers in Plant Science, 7, 1-21.

Ravanel, S., Block, M.A., Rippert, P., Jabrin, S., Curien, G., Reeille, F. ve Douce, R., 2004. Methionine metabolism in plants: chloroplasts are autonomous for de novo methionine synthesis and can import $\mathrm{S}$-adenosylmethionine from the cytosol. Journal of Biological Chemistry, 279, 22548-22557.

Reggiani, R., Nebuloni, M., Mattana, M. ve Brambilla, I., 2000. Anaerobic accumulation of amino acids in rice roots: role of the glutamine synthetase/glutamate synthase cycle. Amino Acids, 18, 207-217.

Rocha, M., Sodek, L., Licausi, F., Hameed, M.W., Dornelas, M.C. ve van Dongen, J.T., 2010. Analysis of alanine aminotransferase in various organs of soybean (Glycine max) and in dependence of different nitrogen fertilisers during hypoxic stress. Amino Acids, 39, 10431053.

Shi, H., Ye, T. ve Chan, Z., 2014. Comparative proteomic responses of two bermudagrass (Cynodon dactylon (L). Pers.) varieties contrasting in drought stress resistance. Plant Physiology and Biochemistry, 82, 218-228.

Sobhanian, H., Razavizadeh, R., Nanjo, Y., Ehsanpour, A. A., RastgarJazii, F. ve Motamed, N., 2010. Proteome analysis of soybean leaves, hypocotyls and roots under salt stress. Proteome Science, 8, 1-15.

Song, H., Zhao, R., Fan, P., Wang, X., Chen, X. ve Li, Y., 2009. Overexpression of AtHsp90.2, AtHsp90.5 and AtHsp90.7 in Arabidopsis thaliana enhances plant sensitivity to salt and drought stresses. Planta, 229, 955-964.

Sun, G., Xie, F. ve Zhang, B., 2011. Transcriptomewide identification and stress properties of the 14-3-3 gene family in cotton (Gossypium hirsutum L.). Functional and Integrative Genomics, 11, 627-636.

Takahashi, Y., Kinoshita, T. ve Shimazaki, K., 2007. Protein phosphorylation and binding of a 14-3-3 protein in Vicia guard cells in response to ABA. Plant and Cell Physiology, 48, 1182-1191.

Tripathi, B.N., Bhatt, I. ve Dietz, K.J., 2009. Peroxiredoxins: a less studied component of hydrogen peroxide detoxification in photosynthetic organisms. Protoplasma, 235, 315.

Urban, M.O., Vašek, J., Klíma, M., Krtková, J., Kosová, K., Prášil, I.T. ve Vítámvás, P., 2017. Proteomic and physiological approach reveals drought-induced changes in rapeseeds: Watersaver and water-spender strategy. Journal of Proteomics, 152, 188-205.

Vítámvás, P., Prášil, I. T., Kosová, K., Planchon, S. ve Renaut, J., 2012. Analysis of proteome and frost tolerance in chromosome $5 \mathrm{~A}$ and $5 \mathrm{~B}$ reciprocal substitution lines between two winter wheats during long-term cold acclimation. Proteomics, $12,68-85$.

Vitamvas, P., Urban, M.O., Skodacek, Z., Kosova, K., Pitelkova, I., Vitamvas, J., Renaut, J. ve Prasil, I.T., 2015. Quantitative analysis of proteome extracted from barley crowns grown under different drought conditions. Frontiers in Plant Science, 6, 479 .

Wang, W., Vinocur, B., Shoseyov, O. ve Altman, A., 2004. Role of plant heat-shock proteins and molecular chaperones in the abiotic stress response. Trends in Plant Science, 9, 244-252.

Wang, X., Cai, X., Xu, C., Wang, Q. ve Dai, S., 2016. Drought-responsive mechanisms in plant leaves revealed by proteomics. International Journal of Molecular Sciences, 17, 1706.

Wang, Y., Fan, K., Wang, J., Ding, Z. tang, Wang, H., Bi, C. ve Sun, H., 2017. Proteomic analysis of Camellia sinensis (L.) reveals a synergistic network in the response to drought stress and recovery. Journal of Plant Physiology, 219, 9199.

Wei, W., Huang, J., Hao, Y.-J., Zou, H.-F., Wang, H.W. ve Zhao, J.-Y., 2009. Soybean GmPHD-type transcription regulators improve stress tolerance in transgenic Arabidopsis plants. PLoS ONE, 4, e7209.

Xin, L., Zheng, H., Yang, Z., Guo, J., Liu, T., Sun, L. ve Guo, L., 2018. Physiological and proteomic analysis of maize seedling response to water deficiency stress. Journal of Plant Physiology, 228, 29-38.

Xu, Y.-H., Liu, R., Yan, L., Liu, Z.-Q., Jiang, S.-C., Shen, Y.-Y., Wang, X.-F. ve Zhang, D.-P., 2012. Light-harvesting chlorophyll a/b-binding proteins are required for stomatal response to abscisic acid in Arabidopsis. Journal of Experimental Botany, 63, 1095-1106.

Xu, J., Xing, X.J., Tian, Y.S., Peng, R.H., Xue, Y., Zhao, W. ve Yao, Q.H., 2015. Transgenic Arabidopsis plants expressing tomato glutathione S-transferase showed enhanced 
resistance to salt and drought stress. PLoS ONE, 10(9), e0136960.

Yan, J., He, C., Wang, J., Mao, Z., Holaday, S.A. ve Allen, R.D., 2004. Overexpression of the Arabidopsis 14-3-3 protein GF14 lambda in cotton leads to a "stay-green" phenotype and improves stress tolerance under moderate drought conditions. Plant and Cell Physiology, 45, 1007-1014.

Yan, S.P., Zhang, Q.Y., Tang, Z.C., Su, W.A. ve Sun, W.N., 2006. Comparative proteomic analysis provides new insights into chilling stress responses in rice. Molecular and Cellular Proteomics, 5, 484-496.

Zadražnika, T., Hollung, K., Egge-Jacobsen, W., Meglič, V. ve Šuštar-Vozlič, J., 2013. Differential proteomic analysis of drought stress response in leaves of common bean (Phaseolus vulgaris L.). Journal of Proteomics, 78, 254272.

Zhang, J., Tan, W., Yang, X.-H. ve Zhang, H.-X., 2008. Plastid-expressed choline monooxygenase gene improves salt and drought tolerance through accumulation of glycine betaine in tobacco. Plant Cell Reports, 27, 1113.
Zhang, S., Li, C. ve Cao, J., 2009. Altered architecture and enhanced drought tolerance in rice via the down-regulation of indole-3-acetic acid by TLD1/ OsGH3.13 activation. Plant Physiology, 151(4), 1889-1901.

Zhang, H., Zhang, L., Lv, H. ve Yu, Z., 2014. Identification of changes in Triticum aestivum L. leaf proteome in response to drought stress by 2D-PAGE and MALDI-TOF/TOF mass spectrometry. Acta Physiologiae Plantarum, 36, 1385-1398.

Zhang, H., Ni, Z., Chen, Q., Guo, Z., Gao, W., Su, X. ve $\mathrm{Qu}, \mathrm{Y} ., 2016$. Proteomic responses of drought-tolerant and drought-sensitive cotton varieties to drought stress. Molecular Genetics and Genomics, 291(3), 1293-1303.

Zhou, Y., Cai, H., Xiao, J., Li, X., Zhang, Q. ve Lian, X., 2009. Over-expression of aspartate aminotransferase genes in rice resulted in altered nitrogen metabolism and increased amino acid content in seeds. Theoretical and Applied Genetics, 118, 1381-1390. 